\title{
CORRIGENDUM
}

\section{A f/oxymoron?: Women, creativity and the suburbs - CORRIGENDUM}

\section{Emma Felton}

doi: http://dx.doi.org/10.1017/qre.2015.27

Published online by Cambridge University Press 16 December 2015

In the opening of the above-mentioned article, the line 'Donald Horne famously wrote, 'Australia was born urban and quickly grew suburban' (1964)', should read: 'Graeme Davison famously wrote, 'Australia was born urban and quickly grew suburban' (1994:98).'

The author would like to apologise for the oversight.

\section{References}

Felton E. 2015. 'A f/oxymoron?: Women, creativity and the suburbs'. Queensland Review 22, pp 168-178. doi:10.1017/qre.2015.27. 